\title{
Environmental Meta-Genome Biotechnology
}

\section{*Abd El-Latif Hesham}

Genetics Department, Faculty of Agriculture, Assiut University, Assiut, 71516, Egypt.

\section{Introduction}

Environmental meta-genome biotechnology is a new field in which genetic material is extracted directly from environmental samples such as soil, sludge, marine, deep sea, freshwater, wastewater, sewage water, food, human gut, insect gut, animals, etc. to understand their microbial community structures by passing the need for isolation and laboratory cultivation of individual microbial species. This new field of advanced molecular genetics research enables studies the vast majority of microbes on earth, of which more than $99 \%$ can not be cultured in the laboratory as well as provides the extensive information on the predicted gene functions and metabolic pathways of diverse environmental microbial communities. for example meta-genome biotechnology technique can be apply for identifying genes from yet-uncultured microbes which have very low or no similarity to known genes in the GenBank .

Advances in the field of genomics and meta-genomics have led to rapid and accurate strategies for the monitoring of microbial biodiversity and have revealed its potential for biotechnological applications. Some of the Meta-genomics techniques based on PCR amplification such as denaturing gradient gel electrophoresis (DGGE), terminal restriction fragment length polymorphism analysis (T-RFLP), rRNA gene clone library, etc., have been widely used for analyzing microbial community structures in various environments. These molecular biological methods avoid the limitation of cultivation and thus reflect the microbes in their environmental community more accurately. Such techniques are based on the detection of nucleic acids, as every microorganism holds unique sequences, which allows the differentiation of microorganisms within complex microbial communities.

\section{PCR-DGGE}

This meta-genomic technique examine microbial diversity based upon electrophoresis of small PCR-amplified DNA fragments (200-500 bp) on an acrylamide gel having a low to high denaturant gradient. In this meta-genomic technique DNA fragments of similar length but with different sequences can be separated according to their melting properties. Individual band can be excised from the gel and identified by sequencing. The main advantages of DGGE are that; it enables the monitoring of the spatial/temporal changes in microbial community structure and provides a simple view of the dominant microbial species within a sample. The DGGE technique has been used to examine the community of bacteria [1-4], yeast [5-8], and fungi [9] and also gene clusters [10].

\section{T-RFLP meta-genome}

T-RFLP analysis is one of PCR-based community profiling method that is commonly used for comparative microbial community analysis based on the position of a restriction site closest to a labeled end of an amplified gene. Briefly, marker genes are amplified by PCR using fluorescently labeled primers at their 5 ' end, followed by digestion using one or more restriction enzymes. Following the restriction digestion, the mixture of fragments is separated using either capillary or polyacrylamide electrophoresis in an automated DNA sequencer and the sizes of the different terminal fragments are determined by the fluorescence detector. Only labeled terminal restriction fragments are detected and their length heterogeneity indicates the complexity of the community visualized by an electropherogram. The major advantage of T-RFLP is the use of an automated sequencer which gives highly reproducible results for repeated samples. T-RFLP was used for the first time to the study of $16 \mathrm{~S}$ rDNA diversity in environmental samples by Liu et al., [11], and has been adopted for the study of bacterial [12], and archaeal [13], communities using rRNA gene systems, and in the study of functional gene diversity like $a m o A$ genes [14].

\section{rRNA clone library}

This meta-genome technique is also based on PCR. The methodology implies the extraction of DNA from an environmental sample, amplification and cloning of the rRNA genes into a suitable vector, followed by sequencing and finally identification and affiliation of the isolated clone with the aid of phylogenetic software. The quality of DNA in terms of size, amount and presence of contaminants should be considered before the library is made as poor quality DNA can lead to low coverage of environmental genomes in the library therefore, purity and recovery of open reading frames from meta-genomic nucleic acids is necessary. Phylogenetic analysis of metagenomic clone libraries bearing rRNA genes has led to the discovery of many new bacterial and archaeal phylotypes in the environmental samples . The method was applied to study the structure of microbial communities such as bacteria and archaeal [15], and yeast and fungi [16,17].

In conclusion, Meta-genome biotechnology is a new field which used to understand the microbial community structures by passing the need for isolation and laboratory cultivation of individual microbial species. Metagenomics is also one of novel approach for engendering novel genes.

\section{References}

1. Muyzer G, de Waal EC, Uitterlinden AG (1993) Profiling of complex microbia populations by denaturing gradient gel electrophoresis analysis of PCR reaction-amplified genes coding for 16S rRNA. Appl Environ Microbiol 59: 695700

2. Muyzer G, Hottentraeger S, Teske A, Wawer C (1996) Denaturing gradient gel electrophoresis of PCR amplified 16S rDNA -A new molecular approach to analyze the genetic diversity of mixed microbial communities. In:MolecularMicrobial Ecology Manual. Kluwer Academic Publishers, the Netherlands.1-23.

3. Gulez G, de los Reyes FL 3rd (2009) Multiple approaches to assess filamentous bacterial growth in activated sludge under different carbon source conditions. J Appl Microbiol 106: 682-691.

4. Hesham A, Qi R, Yang M, (2011) Comparison of bacterial community structures in two systems of a sewage treatment plant using PCR-DGGE analysis. J Environ Sci 23: 2049-2054.

5. Cocolin L, Aggio D, Manzano M, Cantoni C, Comi G (2002) An application of PCR-DGGE analysis to profile the yeast populations in raw milk. Int Dairy $J$ 12: $407-411$

6. Cocolin L, Bisson LF, Mills DA (2000) Direct profiling of the yeast dynamics in wine fermentations. FEMS Microbiol Lett 189: 81-87.

7. Hesham A, Khan S, Liu X, Zhang Y, Wang Z, et al. (2006) Application of PCR-

*Corresponding author: Dr. Abd El-Latif Hesham, Genetics Department, Faculty of Agriculture, Assiut University, Assiut, 71516, Egypt. and Biological Department, Faculty of Science, King Khalid University, Abha, Saudi Arabia. Fax: +20882331384; E-mail: hesham_egypt5@yahoo.com

Received March 20, 2012; Accepted March 22, 2012; Published March 26, 2012

Citation: Hesham Ael-L (2012) Environmental Meta-Genome Biotechnology. Hereditary Genetics 1:e103. doi:10.4172/2161-1041.1000e103

Copyright: (C) 2012 Hesham Ael-L. This is an open-access article distributed under the terms of the Creative Commons Attribution License, which permits unrestricted use, distribution, and reproduction in any medium, provided the original author and source are credited. 
DGGE to analyse the yeast population dynamics in slurry reactors during degradation of polycyclic aromatic hydrocarbons in weathered oil. Yeast 23 : 879-887.

8. Lv W, Hesham A, Zhang Y, Liu X, Yang M (2011) Impacts of cell surface characteristics on population dynamics in a sequencing batch yeast reactor treating vegetable oil-containing wastewater. Appl Microbiol Biotechnol 90: 1785-1793.

9. May LA, Smiley B, Schmidt MG (2001) Comparative denaturing gradient gel electrophoresis analysis of fungal communities associated with whole plant corn silage. Can J Microbiol 47: 829-841.

10. Frapolli M, Moenne-Loccoz Y, Meyer J, Defago G (2008) A new DGGE protocol targeting 2, 4-diacetylphloroglucinol biosynthetic gene phID from phylogenetically contrasted biocontrol pseudomonads for assessment of disease suppressive soils. FEMS Microbiol Ecol 64 :468-481.

11. Liu WT, Marsh TL, Cheng H, Forney LJ (1997) "Characterization of Microbial Diversity by Determining Terminal Restriction Fragment Length Polymorphisms of Genes Encoding 16S rRNA". Appl Environ Microbiol 63: 4516-4522.

12. Clement BG, Kehl LE, Debord KL, Kitts CL (1998) Terminal Restriction
Fragment Patterns (TRFPs), a Rapid, PCR-based Method for the Comparison of Complex Bacterial Communities. J Microbiol Methods. 31: 135-142.

13. Chin KJ, Lukow T, Stubner S, Conrad R (1999) "Structure and Function of the Methanogenic Archaeal Community in Stable Cellulose-Degrading Enrichment Cultures at two Different Temperatures (15 and 30 degrees C)". FEMS Microbiol Ecol 30: 313-326.

14. Horz HP, Rotthauwe JH, Lukow T, Liesack W (2000) Identification of Major Subgroups of Ammonia-Oxidizing Bacteria in Environmental Samples by T-RFLP Analysis of amoA PCR Products. J Microbiol Methods 39: 197-204.

15. Liu R, Li D, Gao Y, Zhang Y, Wu S, et al. (2010) Microbial diversity in the anaerobic tank of a full-scale produced water treatment plant. Process Biochemistry 45: 744-751.

16. Gao Z, Li B, Zheng C, Wang G (2008) Molecular Detection of Fungal Communities in the Hawaiian Marine Sponges Suberites zeteki and Mycale armata. Appl Environ Microbiol 74: 6091-6101.

17. Singh P, Raghukumar C, Verma P, Shouche $Y$ (2011) Fungal community analysis in the deep-sea sediments of the Central Indian Basin by cultureindependent approach. Microb Ecol 61: 507-517. 